\begin{tabular}{c} 
Volume and Issues Obtainable at Center for Sustainability Research and \\
Consultancy \\
Sustainable Business and Society in Emerging Economies \\
ISSN: 2708-2504 \& ISSN (E): 2708-2172 \\
Volume 3: Issue 4 December 2021 \\
ᄃSRᄃ \\
Journal homepage: www.publishing.globalcsrc.org/sbsee \\
\hline
\end{tabular}

\title{
Inter-tribal Conflict effects on Educational Development in Yemen: A Qualitative Analyses
}

*Anef Taher, Ph.D. Scholar, Department of Sociology, University of Peshawar, Pakistan Zafar Khan, Lecturer in Sociology Department, University of Peshawar, Pakistan

Shaista Irshad Khan, Assistant professor, Department of Education, Abdul Wali Khan University Mardan, Pakistan

*Corresponding author's email address: anef2011@ yahoo.com

ARTICLE DETAILS

History

Revised format: Nov 2021

Available Online: Dec 2021

Keywords

Educational Infrastructure, Educational Development, Intertribal Conflict; Yemen.

\section{JEL Classification}

I210, 250, 310

\section{OPEN ACCESS}

ABSTRACT

Purpose: The current inter-tribal conflict and economic crisis have impacted all aspects of life in Yemen, especially hampered the development of education. This study focuses the inter-tribal conflict effects on the development of education

Approach: This is achieved by collecting data applying qualitative tools of data collection. The data was collected from the students, teachers and tribal elders in Aden and Taiz through in-depth interview and focused group discussion. The data analyzed in the light of different themes derived from the primary data

Findings: The results indicated that the intertribal conflict has significantly affected the education infrastructure. Moreover, we found that inter-tribal conflict hampered the process of the development. More importantly, the educated people left the county and the government and people are not investing in the educational sector Implications/Originality/Value: For the development of (education in) Yemen, all the political parties in the nation and regional and international communities must show more responsibility and commitment towards the current and future generations of Yemen and the world.

(C) 2021 The authors, under a Creative Commons AttributionNonCommercial- 4.0

Recommended citation: Taher, A., Khan, Z. \& Khan, S. I. (2021). Inter-tribal Conflict effects on Educational Development in Yemen: A Qualitative Analyses. Sustainable Business and Society in Emerging Economies, 3 (4), 557-566.

\section{Introduction}

The current inter-tribal conflict was started in March 2015 between the rebellion group Houthi (supported by Iran) and the government of Yemen (reinforced through Saudi controlled alliance) over resources then power-sharing (Coppi, 2018).

\section{Inter-tribal Conflict in Yemen}

The inter-tribal conflict in Yemen in the present time periods is divided into two phases. One was started in 1994 between the South and North and the current one began in 2004 that continues till date between 
Houthi and Yemen government (Al Dosari and George, 2020). The conflict in the south of the country has given rise to a powerful separatist movement. The Houthi conflict paved the way for a religion-led conflict of identities among the north and south tribes of Yemen. This undermined the unity. The warring groups have different tribal identities. The tribal conflicts often arise among the tribal elites over the power and the tribal elites fight against each other for gaining power (Manea, 1996). The recent inter-tribe conflict is between different tribal groups such as the Houthi group (with the majority of Northern Yemeni tribes) and the government (which is also the coalition of different tribes) (Coppi, 2018). The conflict between the Houthi and government is also considered the inter-tribal conflict. They have joined different coalition on the basis of tribal loyalties.

\section{Focus of the Present Study}

The current inter-tribal conflict has damaged all levels of education in Yemen, and the children and young people are deprived of their basic rights. There are more than millions of children out of educational institutions. However, research has not yet been conducted to investigate the current intertribal conflict in Yemen and its impact particularly on the educational development. This research investigates the inter-tribal conflict impact on the development of education in Yemen. It is necessary to highlight the challenges to education in Yemen after the initiation of the current conflict. This research also focuses on changes that occur in the education system.

\section{Literature Review}

\section{Inter-Tribal Conflict as an Obstacle to Development of Education}

Several studies discuss the relationship between conflict and education inequality. The conflict exacerbates inequalities in education levels among people. Shemyakina (2011) shows that the conflict pre-existed gender gaps increased and raise the gender inequality in Tajikistan, and the educational attainment suffered especially among poor women. A lot of studies have been conducted regarding the influence of inter-tribal battle on teaching in different parts of the world (Breidlid, 2010, Khan, 2015).

The conflict has the worst impact on educational institutions at the global level and as well as in Yemen. Conflicts reduce the enrolment ratio of students throughout the world. It increases the drop out ratio in educational institutions during the war (Omoeva, Hatch, \& Moussa, 2016). Akresh, De Walque (2008) Rwanda and Justion (2006) Akresh and De Walque (2008) found that education level reduced among poor and non-poor in Rwanda during the tribal conflict. The level of education was going down as a consequence of the conflict which is tribal, especially amongst the poor scholars. Valente (2011) got the same result in Nepal, saying that the conflict badly affected education institution during 1996 to 2006. Conflict increases the ratio of migration among educated people. Migration of educated people affects the educational institutions and there are educational institutions that face the problem of faculty and facilities to teach the different subjects. Moreover, many studies' empirical results prove that conflict undermines education and the links between conflict and education are numerous and complex. Conflict affects educational quality and decreases educational budget. Conflict also significantly decreases the attendance of teachers and students (Justino, 2016). Displacement has the worst effect on education during conflicts. The majority of the population from the conflict zone has been displaced from the conflict zone at the global level. The displaced population live in camps and they have no access to educational institutions. Children of the displaced population are not able to get an education.

Educational institutions have an important role to train children and provide them knowledge. Schools boost their sense of identity and inclusion and provide a chance related to self-appearance and integration by other students (Nicolai, \& Triplehorn, 2003). Moreover, Smith (2014) believed that school trains children to learn skills and resolve their socio-political problems in logical manners. Education also protects children from child soldiering and abduction. However, in comps, they are exposed to physical and sexual violence. The displacement children are vulnerable to sexual abuse and abduction. Moreover, the tribal conflict has a negative impact on students and teachers. They are not safe now in educational institutions. 
School buildings are a soft target for the tribal militia (Akresh, \& Walque, 2008). Gómez (2017) seeks to understand the effects of conflicts especially civil conflicts on educational institutions. The aim of his research is to understand the educational achievements of students who live in conflict and non-conflict zones in Colombia. I used different approaches to measure the student's learning advantages. In some cases, it is also noticed that conflict increased the learning opportunities among the students because of hardship they face during conflict. Students develop resilience during conflict and it make them enable to face difficult situation. They can easily continue their studies during conflict. It shows conflict increases resilience among the students to continue education in a hard time.

Businge (2015) conducted research on the education of children with disabilities in the conflict zone. He attempted to understand how children with disabilities are educated in the armed conflict settings of Uganda and how their settings could be improved. In the conflict zone, disabled children are more affected as compared to normal children. They are more vulnerable to insecurity in educational institutions. They cannot run to protect themselves in the time of attraction.

Nasongo and Muola (2011) explored the psychological disorder caused by the inter-tribal conflict in Kenya and also investigated the effects on the secondary schools' students' academic performance. The within-ethnic battle in Kenya continued for so extended period and it started among the land dispute between the Soy and Ndorobo clans of the Sabaot tribe. The research work focused the shock and social disorder caused by the conflicts which are within tribe. Most of the defendants (98\%) stated that the battle badly affected the performance related to academic within examinations which are based on classroom.

Ahmed (2015) also conducted research to investigate the influence of armed conflict on students' performance in Mender North Sub-County. He formulated four basic goals to establish the effects of displaced families, destruction of school infrastructure, and destruction of the source of livelihood on the students' performance during armed conflict. The sampling includes eight head teachers and 112 students in primary schools who were randomly selected. The result shows that due to the displacement of families and teachers the educational institutions face shortage of teachers and teachers try to get jobs where they do feel secure. The performance of students suffers because of the infrastructure damaged during the armed conflict which destroys schools, and educational infrastructure. Displaced students become poor and they are the great victims of violence, malnutrition, disease. Children do not show satisfactory performance and they are more susceptible to physical and sexual violence. It badly affects the mental health of students which creates many problems for their lives in the present time and future Davies (2011) also investigated the effect internal war on the population the population of twenty-five countries that include Yemen and Pakistan and finding substantial negative effects on educational institutions and literacy. In a conflict zone, a small number of children have access to formal education, a decrease education ratio, and a literacy rate. The effects of the conflict continue for a long time. The conflict also increased violence against the women and they have been deprived from their right to education in the different countries of the world. Women are children are more exposed to violence during the conflict. They draw data majorly from two survey programs: demographic and surveys related to health (DHS) and Surveys related to Multiple Indicator Cluster (MICS). The size of the sample ranges after around 21,000 within Bosnia and Herzegovina towards around 727,000 in Pakistan. These two reports show a huge impact of conflict on marginalized groups such as women and children. Women and children are more marginalized as compared to men. In conflict, they are more affected as compared to men. Women and children are more vulnerable and they are more affected during the conflict in different parts of the world.

Okoye (2013) showed an education related to Ethno-Religious Conflict within Northern Nigeria. This focuses on different aspects of inter-tribal conflict and as well as explore the genocide in Nigeria. For this purpose, he accepted a gratified examination and beached philosophy of practice which is based on Strauss and Corbin's (1990) approach. He used triangulation and authentic citations to increase the 
trustworthiness of his study. For the analysis, he used Nvivo software program for the examination of content. His sample contained of 197 newspapers where articles happening on the conflict were published in Nigeria. He revealed that various socio-political factors sustained the fierce battle amid radical Muslims and Christians within north of Nigeria. This study puts prominence happening regarding the cultural and spiritual magnitudes of the north of Nigerian conflict. The main research question was around genocidal predispositions towards the ethno-religious battle and in north of Nigeria. Ethnic then religious factors fueled battle within north of Nigeria that resulted in the death of a number of people in this war. Globally, the inter-tribal conflict has a negative impact on the educational institutions and it decreases the ratio of student's enrolment. However, the inter-tribal conflict in Yemen also affected the educational institutions. The following lines describe the social, political, and economic impact of the inter-tribal conflict.

\section{Education Development Impact of Inter-Tribal Conflict on Yemen}

Inter-tribal conflict displaced in million the local people and damaged the property. It is also distorted the local social and cultural institutions and the people lost their native town and resources. It caused starvation and disrupt the developmental plan. Hunger and food starvation affected a number of people and it also fuels violence in the different parts of Yemen. The number of people has been killed in the inter-tribal conflict and damaged the public infrastructure include hospitals and schools (Economic Studies and Forecasting Sector, 2019).

Yemen is the self-effacing republic within Middle East. Although Yemen, like other Gulf countries, has oil, the economic benefits have been exploited mainly in the north by the Hashid tribe to which former president Ali Abdullah Saleh belonged. Yemen is the Arab world's poorest country, with a poverty rate of more than 50\%25, and has a low Humanoid Growth Directory score, hierarchical 160 available of 188 republics (Carrasco, 2016). In the current inter-tribal conflict, Yemen is facing tremendous challenges in socio-economic development, political stability and security. The trend of development in Yemen has been associated with events that played havoc with the political and military situation for more than five years, particularly in the city of Taiz (Salisbury, (2017). The inter-tribal conflict created a lot of problems especially undermines the development of the country. The progress of socio-economic development become halted as a consequence of bury-ethnic battle.

The conflict has pushed the country to the verge of famine. About 7.6 million people are at the risk of starvation. This has placed the population at risk for contagious diseases like cholera and dysentery (Sowers, and Weinthal, 2021). It has also damaged the education infrastructure, school buildings, roads, equipment, security staff and education system. Almost half of the student's country lacks access to educational institutions. Heavy bombardment and airstrikes have hampered students and teachers' access to educational institutions and increased the pressure on the education facilities that are still functioning. It has damaged the education quality and the whole system. All of this has resulted in shaky education development (Salisbury, 2017).

Rendering to the Humanoid Growth Account Office, the main declines in Human Development Index) HDI) vigorous remained in battle-pretentious republics within the Syria (27 down), the Libya (26), and the Yemen (20) due to conflict and the importance on war cheap at the spending of the shared and emerging insistences, the major ones of which are education and health. Rendering to the Humanoid Growth Account Workplace, the main declines in Human Development Index vigorous were in battlepretentious republics within Syria (27 down), Libya (26), and Yemen (20) owing to conflict and the emphasis on war cheap at the expenditure of the communal and developing urgencies (UNDP. 2018. Humanoid Growth Directories and Pointers, 2018). These republics will take years to recover the preconflict heights of growth.

For almost three decades, Yemen has expanded education. The quality of education services also improved in Yemen. The literacy ratio was improved in during peaceful situation in Yemen (Yuki and 
Kameyama, 2013). However, the ratio of education has been decreased during different inter-tribal conflicts. The data reveals during the time of peace among the different tribes the education increased in the past. Its growth continues at rate of 22 out of a hundred toward ended 4 million in 2007-08. Employments in practical teaching and occupational exercise (TEVT) augmented in the past. Meanwhile, higher education grew 35 times more from nearly 5,000 to 175,000 from 1977 to 2000. Advanced teaching sustained to upsurge by 34 percent in 2008. Assumed Yemen's demographic, physical, and financial tests, this growth is truthfully extraordinary (Al-Hattami, 2012). The current conflict in Yemen affected the development process and damaged education infrastructure. Both military expenditure and conflict retarded the education development (Collier, P. (2006). In addition to taking lives, the inter-tribal conflict in Yemen also stains the future of students in Yemen where whole generation is at risk (Zabarah, and Mutalib, 2019). Consequently, the education in Yemen needs humanitarian support in all sectors, protection of students and teachers, essential services and infrastructure.

\section{Educational Development}

We attempt to briefly discuss the concept of educational development (ED) from different perspectives. For instance, supporting universities and colleges to function effectively is the main meaning and function of ED (Felten et al., 2007). The concept of ED relates to 'actions' (POD Network, 2016) that focus on enhancing the teaching activities (Amundsen \& Wilson, 2012). Further, ED is a 'key lever for ensuring institutional quality and supporting institutional change' (Sorcinelli, Austin, Eddy \& Beach, 2005, p. xi).

In Table 1 below, adapted from Liu's study (1967) that proposed a measurement framework for ED, we present that countries are first classified into three categories based on many indicators, and other several indicators are proposed to increase the level of ED.

\section{Procedure}

The first step was collecting data from eight tribe leaders' who are belong to Aden province and surrounding (Yafia, Lahj, Dar Saad, Al-Subiha and Abian). They were selected because these tribes are the part of the different tribal alliances. Schools are mostly damaged in the areas where these tribal are living and there are many refugees still living in schools' institutions. Secondly, the data were collected from 10 leaders of Taiz tribe's province, belong to six areas (Saber Almisraq, Sharab shameer and Mawiah). The selection of these leaders' tribes was based on the purposive sampling and data was collected through in-depth interview. The security situation make it difficult for us to contact all the tribal leaders and we collected data from 18 tribal leaders. We stop data collection on the saturated point where most the questions answers were repeating. Results and Discussion

There were 18 tribe leaders' respondents in this study. With the permission of the tribal leaders, the data was recorded. The data was collected in Arabic language and we translate it into the English language. Then, carefully different themes derived from the data to explore the factors which hampering the process of the development education in Yemen. Moreover, the primary data juxtaposed with secondary data.

\section{Analysis of Negative Effects on the Development of Education in Yemen}

Congenial environment in which education development is taking place has been changing rapidly during the inter-tribal conflicts. As a result of inter-tribal conflict, political instability, and mismanagement in educational institutions, the destruction of educational infrastructure and security problems collectively jeopardized the Yemen education system. Education is a vital component in economic development. The significance of education cannot be ignored for the socio-economic development. It contributes to build human resource and produces skilful work-force for development. It is necessary for the development to build educational institutions, invest in physical infrastructure, and make quality education accessible for everyone (Lewis, 2007). Development reduces poverty, unemployment, and provides opportunity to maximum number of people. Pearson (1992) also asserts 
that development refers to a myriad of strategies adopted for socio-economic and environment transformation or desirable socio-economic change (Abuiyada, 2018). The majority of academicians, economists' and planners argued that socio-economic development does not occur without skilful people. Therefore, for the development, strong and well-equipped educational institutions are resources. Human resources play a vital role in the national development and skillful individual active involvement in socio-economic development.

Violent conflict is the biggest barrier to development in many of the poorest countries (Ray \& Esteban, 2017). The inter-tribal conflict targets educational institutions and destroys the school buildings (Smith, Alan, and Tony, 2003). Gates et al. (2012) prove that inter-tribal conflict increases undernourishment, infant mortality rates, and destroyed socio-political educational institutions. War and conflict also increased the ratio of poverty.

According to Murdoch (2002) and Sandler, inter-tribal conflict affected the economic growth. It affected the available infrastructure of economic growth. Investors do not invest in those countries where the security situation is not satisfactory. In this regard, one respondent stated that:

The inter-tribal conflict is hampering the process of development in Yemen especially the education system. The maximum of the budget goes to support the military and their salaries in Yemen. There are no development projects and the old projects have come to standstill including educational projects. Alsabri (Personal communication February 10, 2019).

The government of Yemen is virtually non-existent. The government failed to protect and spend budget on educational institutions which were damaged by inter-tribal conflict. Civil society and community organizations are working to rebuild the educational institutions and the government does not have the capacity to protect the humanitarian organizations.

Local and foreign reports confirm that the development project suspended in Yemen and there are no projects launched for the rehabilitation of educational institutions. Non-government organizations encouraged women's associations, teachers' unions, local communities to rebuild schools and universities (Jones, 2005). Moreover, damage of inter-tribal conflict on education is enormous. In this regard, one respondent stated that:

"As a result of inter-tribal conflict, I services sector is paralyzed. It has also destroyed the infrastructure which hampers the process of development. The economy has deteriorated due to a lack of resources and income. It is alarming that people are suffering due to poverty and social activities are curtailed." Muhammad Kalifa (Personal communication February 10, 2019).

This situation compelled the poor people and forced them to work in insecure environment to earn a livelihood for their families. The poor do not have any alternative but to work in an insecure environment. (Selwyn, 2013).

\section{Inter-tribal Conflict Effects on the Development of Education in Yemen}

Education is important tool for human development. Education plays a vital role in development and it provides a foundation for knowledge and skills which are essential for the sustainable socio-economic development. The government reduced the budget of education and spent money on weapons and military. In this regard, Fahmi stated that.

"In recent years, during the inter-tribal conflict, the education budget has been consumed by security forces and it is difficult for the government to spend money on education and provide facilities to educational institutions. The government does not have the money to rebuild the infrastructure which is fully or partially damaged in the current inter-tribal conflict" Fahmi (Personal communication February 10, 2019). 
The educational institutions in Yemen were not developed before the inter-tribal conflict but the current situation further negatively affected education. Educational institutions became easy targets from the tribal militias and, therefore, the educational institutions and students were more affected this current tribal war. The inter-tribal conflict jeopardizes teachers and students' life. Smith, Alan, and Tony (2003) show that due to conflict there are $82 \%$ of the reported 113 million children out school. One respondent stated that:

Many students and teachers left school due to the current inter-tribal conflict. They are forced to live in this native town and doing normal work inside the country or abroad. Students and teachers are recruited into a private militia or army by force" Umar (Personal communication February 10, 2019).

Conflict hampers the process of educational development and directly damages the education infrastructure; economic collapse and massive migration is the result. There are 10.6 million people who are displaced by conflict in Africa (Smith, Alan, \& Vaux, 2003). The inter-tribal conflict also displaced millions of people in Yemen and badly affected the educational institutions as well. In this regard, one respondent stated that:

The migration of qualified and trained workers from the country has badly affected the education system of Yemen which puts great burden on society. The government has completely failed to provide services including security to the people. The education sector has been paralyzed. The inter-tribal conflict has the financial and psychological effects on the students and teachers. The students and teachers learnt violent behavior. The majority of educational institutions face the problems of human resources. Mosque, and open places are used as classrooms for education purpose in Yemen because there is no infrastructure available for the education" Muhammad Rajih (Personal communication February 10, 2019).

The inter-tribal conflict has deprived people to get education. Human resources are regarded as one of the more important factors for development. Education stills are -considered important in the industrial development. The human resource helps us in the process of development. In the present time, countries are racing to attract inventors----educated people who have special skills and abilities. Essam, teacher in al Moshiky School, in this regard stated that:

A lot of qualified and educated workers left Yemen and got a job outside. Brain drains and skillful people migrated from the country which has put a greet burden on the society. The society lost its finest youth” Abd AL Rahman (Personal communication February 10, 2019).

Moreover, foreign countries stopped the investment flow and it also affected the educational institutions. Yemen has failed to attract foreign capital and investments and Yemen failed to provide new job opportunities for their workers due to inter-tribal conflict. The attraction of foreign capital and investment is one of the most important factors that create economic development societies. Therefore, the weak economy of Yemen also creates obstacles in the development of education. There is a lack of adequate equipment's and modern educational means are not present, and all kinds of laboratory equipment's have been stopped due to lack of financial resources. Schools have been merged with other schools due to limited spaces and lack of basic services. Schools have turned into places when the different tribes train the students according to the won ideology (Ray and Esteban, 2017). Influence on the teachers and curriculum to change education according to their own interest is necessary. The tribal leaders try to mobilize people and especially young people. One tribal leader stated that.

"Often the tribe participates in the war for its own self-interest. The opponent groups are trying to attract the tribes to participate in the conflict through money, reward, positions and jobs or force them by threats, accusing them of treason and detaining members of the tribe" Hanafi (personal Communication Jan 20, 2021). 
The tribes are worried about their self-interest and poor people join tribal militia only for financial reasons. Elbadawi \& Sambanis (2000) confirmed that the majority of poor people join the tribal militia due to poverty. Moreover, the Yemen tribes join the militia due to political instability and poverty (AlDawsari, 2012). Zayd, leader of Sharap community, in the Taiz city in this regard stated that.

Common people are worried about their children education after the inter-tribal conflict. The tribal people move from rural areas to unban cities for their children education. Unfortunately, now in this conflict children are not safe in educational institutions. Kamal (personal communication Fab, 12, 2020). Armed groups try to occupy educational institutions and also try to bring change in the curriculum of the education for their own vested interests. Tribes are worried that their children's mind-set has been changed and they have become violent.

Armed groups exploited this current conflict period to spread their extremist ideas in schools and create a generation that embraces their views in Yemen society. For this purpose, the armed groups imposed a curriculum according to their beliefs and ideological ideas. Kamal, leader in Al-Thalia (personal communication, Fub 12, 2020).

This current inter-tribal conflict creates multiple ideological groups based on tribal loyalties and religion. Children became deprived of basic goals. The current education system has not been contributing to the development of Yemen's education system but for creating ideological cleavages in Yemen society. It has become a tool of suppression. In this regard, Isam, stated that:

Armed groups exploited youth and teenagers and motivated them to fight for them. They also threatened teachers to support these ideological groups in school. The armed groups spread terror among the school students. Education has no or little contribution to development. Isam leader in Shik Othamn (personal communication, 12 Fob, 2020.

The inter- tribal conflict hampers the process of development and there is no infrastructure available for the students to provide education. Students and teachers are also not a safe and secure. For the development of education, it is important to provide safe and secure environment. In addition, Isam said that.

During the inter-tribal conflict, the militias have a direct and indirect influence on the education system. They control teachers' salaries, education programs, curriculum, the activities of teachers and students. Teachers' unions are directly controlled by the armed groups of tribal militias. They also control the students' unions and use them for this won self-interest. The armed groups punish the students and teachers who deny and do not follow their order. Islam, (personal communication, Fub 13, 2020).

Education development needs a peaceful and secure environment. Furthermore, the human resources and development budget are repaired for the development of education. In the current war, the available infrastructure is affected. The government is not in a position to support the educational institutions.

Conclusion

The inter-tribal conflict badly affected the development of education. The educational institutions have badly damage damaged. Inter-tribal conflict has persisted over the years in Yemen and the current conflict is still going on at this study time. This inter-tribal conflict is more devastating in some areas of Yemen such as Aden and Taiz where this study was carried out. Both cities are mainly inhabited by members of military tribes during this conflict. Both cities community comprised of civil people who came from every part of Yemen. The conflict between government and Houthi rebel tribes over governance issues dates back to March 2015. The conflict has been a result of government's attempts regain the capital Sana'a of the Houthi tribes. According to the outcome of this study, the inter-tribal conflict which intensified in 2015 damaged a lot of educational institutions. The destruction in education 
infrastructure at a higher level of education institutions in Yemen has played havoc with the country. The infrastructure of facilities has been damaged and their contents are stolen. Most of the educational institutions are destroyed, almost completely, partially or they are unfit for using. The impact of the conflict on the education infrastructure in the cities of Aden and Taiz has made the cities unsafe. A result of this inter-tribal conflict, $\mathrm{d}$ more than 4,000,000 students were displaced and more than 1.5000 .000 of children went out of school. The output showed that inter-tribal conflict badly affected education infrastructure in Yemen. The inter-tribal conflict along with multi-faceted disastrous effects has also negatively affected the students and teacher's behavior. It has been revealed that during the inter-tribal conflict the students and teachers have been exposed to violence. They have been deliberately exposed to violence and targeted by the tribal militia. It has been found that they are easily targeted and students are easy target for the tribal militia. It has been explored that violent environment that emerged out of inter-tribal conflict exposed the students and teachers to learn violent behavior. The inter-tribal conflict in Yemen is considered as a complex issue in this research. It is only study found on the inter-tribal conflict and its effects on educational institutions. There are other areas which need to be explained in future. The history of the inter-tribal conflict in Yemen needs to be explored. Moreover, resources should be conducted to see the effect of inter-tribal conflict on women.

\section{References}

Akresh, R., \& De Walque, D. (2008). Armed conflict and schooling: Evidence from the 1994

Rwandan genocide. The World Bank

Benard, C., Kvaerno, O., Thruelsen, P. D., Cordell, K., Rabasa, A., Jalali, A., \& Rasmussen, $\quad$ M. V. (2008). Afghanistan: State and society, great power politics, and the way ahead. Santa Monica: RAND Corporation.

Buckland, S. T., Anderson, D. R., Burnham, K. P., \& Laake, J. L. (2005). Distance sampling. Encyclopedia of biostatistics, 2

Central Intelligence Agency. (2010). the World Fact book: Yemen. Retrieved February, 19, 2018 from https://www.cia.gov/library/publications/the-world- factbook/geos/ym.html

Coppi, G. (2018). The humanitarian crisis in Yemen: Beyond the man- made disaster. International

Peace Institute. Retrieved from: 2-40. https://www.ipinst.org/wp-content/uploads/2018/01/IPI-RptHumanitarian-Crisis-inYemen.pdf.

Gleditsch, N. P., Wallensteen, P., Eriksson, M., Sollenberg, M., \& Strand, H. (2002). Armed conflict

1946- 2001: A new dataset. Journal of peace research, 39(5), 615-637

GoY. (2013). Presidency of the supreme council for planning education. Sana'a: Yemen.

Hofs, M. (2017). Identities and narratives as social constructs: The making of sectarian war in Yemen: (Unpublished Master thesis). Leiden University, Netherlands.

Hokayem, E., \& Roberts, D. B. (2016). The war in Yemen. Survival, 58(6), 157-186. http://www.unocha.org/yemen/aboutocha- Yemen

Lai, B., \& Thyne, C. (2007). The effect of civil war on education, 1980-97. Journal of peace research, 44(3), 277-292

Manea, E. M. (1996). Yemen, the Tribe and the State. In international colloquium on Islam and Social Change, University of Lausanne (pp. 10-11)

Mason, E. S., \& Asher, R. E. (2010). The World Bank since Bretton Woods. Washington D.C.USA: Brookings Institution Press: 4-43

Metz, H. C. (1994). Persian Gulf States. For sale by the Supt. of Docs., USGPO.

Muthanna, A., \& Sang, G. (2018). Conflict at higher education institutions: factors and solutions for Yemen. Compare: A Journal of Comparative and International Education, 48(2): 206- 223.

Smith, A., \& Vaux, T. (2003). Education, conflict and international development. Research Report, Institute for Research in Social Sciences. Retrieved on 08/10/18 from: 1-72. http://www.dfid.gov.uk/Documents/publications/edconflictdev.pdf

Swee, E. L. (2009). On war and schooling attainment: The case of Bosnia and Herzegovina (No. 57). Households in Conflict Network.

Rodriguez, C., \& Sanchez, F. (2012). Armed conflict exposure, human capital investments, and child 
labor: evidence from Colombia. Defence and peace economics, 23(2), 161-184

Vis, A. S. (2016). Framing the war in Yemen: narratives of aggressive neighbours, internal extremism, and humanitarian crisis. (Unpublished Master's thesis. Faculty of Humanities Theses. Utrecht University. Netherlands)

United Nations International Children's Emergency Fund (UNICEF). (2016). Yemen the impact of violence and conflict on Yemen and its children.3-15 Retrieved on 07/10/18 from https://www.unicef.org/spanish/media/files/Yemen--Fragile to_Failed.pdf

United Nations International Children's Emergency Fund (UNICEF). (2017) .Yemen situation $\quad$ report. $\quad$ Retrieved $\quad$ on $19 / 02 / 2018$ from https://www.unicef.org/appeals/files/UNICEF_Yemen_Humanitarian_Situation_ Report_May_2017.pdf.

United Nations Development Programme (2018). Yemen: Country Profile. Last modified February. 19 2018. http://www.undp.org.ye/y-profile.php. 